\title{
ANALISA KINERJA PADA PERUSAHAAN SUPLAIR PRODUK KABEL DI INDONESIA
}

\author{
Haryadi Sarjono \\ BINUS Business School Undergraduate Program, \\ Bina Nusantara University \\ e-mail : haryadi_s@binus.edu \\ Ahmad Nabil \\ BINUS Business School Undergraduate Program, \\ Bina Nusantara University \\ e-mail : ahmadnabil12@ hotmail.com
}

\begin{abstract}
The purpose of this study was to determine the effect of Total quality management, Quality management information, and competitive advantage affect company performance. The object of research is all employees of PT. Nusa Jayatama Mandiri, data collection techniques by distributing questionnaires to all employees of the company as many as 132 respondents and direct observation to the company. Data analysis method using multiple linear regression analysis with IBM SPSS 22. The results of research Total quality management has a positive and significant effect on company performance, Quality management information has a positive and significant effect on company performance, competitive advantage has a positive and significant effect on company performance. Total quality management, quality management information, and competitive advantage together affect the company's performance.
\end{abstract}

\begin{abstract}
ABSTRAK
Tujuan penelitian ini adalah untuk mengetahui pengaruh Total quality management, Quality management information, dan keunggulan kompetitif berpengaruh terhadap kinerja perusahaan. Objek penelitian adalah seluruh karyawan PT. Nusa Jayatama Mandiri, teknik pengumpulan data dengan menyebarkan kuisioner kepada seluruh karyawan perusahaan sebanyak 132 responden dan observasi langsung ke perusahaan. Metode analisis data dengan menggunakan analisis regresi linier berganda dengan IBM SPSS 22. Hasil penelitian Total quality management berpengaruh positif dan signifikan terhadap kinerja perusahaan, Quality management information berpengaruh positif dan signifikan terhadap kinerja perusahaan, keunggulan kompetitif berpengaruh positif dan signifikan terhadap kinerja perusahaan. Total quality management, Quality management information, dan keunggulan kompetitif secara Bersama-sama berpengaruh terhadap kinerja perusahaan.
\end{abstract}

Kata Kunci : Total quality management, Quality management information, keunggulan kompetitif, kinerja perusahaan.

\section{PENDAHULUAN}

Pembangunan infrastruktur di Indonesia dalam sepuluh tahun terakhir ini mengalami kemajuan yang sangat pesat. Dalam kurun lima tahun terakhir lebih terlihat khususnya dalam pembangunan infrastruktur Jalan Tol, Fasilitas Bandara dan Pelabuhan serta sektor 
Telekomunikasi dan Ketenagalistrikan. Menurut CNBC Indonesia, 2019, anggaran belanja negara untuk infrastruktur di tahun 2019 mencapai angka Rp 420 M. (empat ratus dua puluh triliun Rupiah). Angka ini meningkat sebesar 157\% dari tahun 2014 yang hanya Rp $163 \mathrm{M}$. (seratus enam puluh tiga triliun Rupiah). Membangun infrastruktur di seluruh penjuru negeri, tidaklah mudah. Namun, melalui kerja keras dan tekad yang bulat, pemerintah berhasil melakukan berbagai macam pembangunan infrastruktur bagi rakyatnya. Berdasarkan CNBC Indonesia yang mengutip data hasil pembangunan infrastruktur dari Kementrian Pekerjaan Umum dan Perumahan Rakyat (PUPR) pada tahun 2019, terdapat 55 bendungan yang dibangun dalam 4 tahun terakhir, selain itu terdapat lebih dari 800.000 Hektar daerah yang sudah mendapat jaringan irigasi. Selain itu terdapat 942 embung yang dibangun dalam 4 tahun terakhir, demikian pula jalan yang sejak 2014 hingga 2019 sudah dibangun sejauh 3.387 Kilometer, demikian juga dengan jalan tol yang sudah dibangun sebanyak $1.852 \mathrm{Km}$ sejak 4 tahun terakhir. Pembangunan dan peningkatan Infrastruktur Ketenagalistrikan di Indonesia juga mengalami angka yang cukup signifikan hal ini ditunjukan antara lain dengan beberapa proyek kelistrikan yang meliputi Pembangunan Pembangkit Listrik, Pembangunan Jaringan Listrik Transmisi dan Distribusi. Dilansir dari website Kementrian Perindustrian, proyek listrik di Indonesia mengalami peningkatan, sehingga jumlah permintaan akan kabel meningkat dengan pesat. Dengan maraknya pembangunan proyek kelistrikan yang dilakukan oleh pemerintah tersebut, Asosiasi Pabrik Kabel Indonesia (APKABEL) memperkirakan permintaan kabel pada tahun 2019 meningkat sekitar 20\%. Peningkatan di tahun 2019 sebesar $20 \%$ ini akan memberikan dampak positif dalam bisnis kabel di Indonesia, karena baik dari sektor pemerintah yaitu PLN dan pihak Swasta memiliki tingkat permintaan yang semakin meningkat, seiring berkembangnya perkembangan infrastruktur di Indonesia pada tahun 2019 ini, sementara di tahun 2018, permintaan kabel hanya naik 10\% dari tahun 2017 dan permintaan kabel di tahun 2017 juga hanya meningkat 10\% dari tahun sebelumnya di 2016. (wartakota, tribunnews.com 2019). Data Kebutuhan Kabel Listrik dari tahun 2016 sampai dengan 2019.

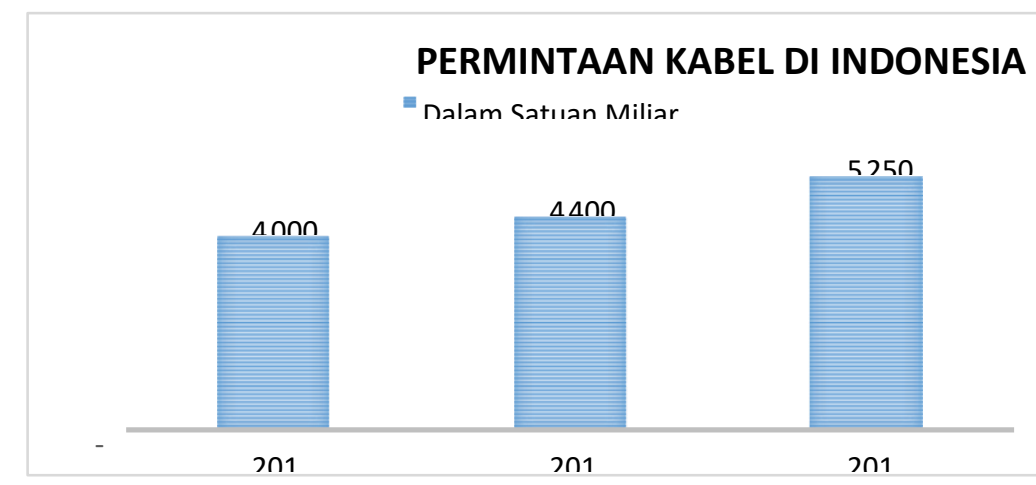

Sumber: Tribunnews (2019)

Gambar 1. Permintaan Kabel di Indonesia

Berdasarkan gambar 1. Peningkatan permintaan kabel di Indonesia sejak tahun 2017 sebanyak 4.000 meningkat menjadi 5.250 (Milyard Rupiah) pada tahun 2019. Pembangunan Jaringan Transmisi dan Distribusi Listrik yang dilakukan meliputi Jaringan yang dibangun oleh pihak Pemerintah dalam hal ini PT. PLN, sedangkan sebagian lagi dibangun oleh pihak Swasta. PT. PLN lebih fokus kepada Pembangunan. Jaringan Tegangan Tinggi dan Menengah, sedangkan pihak Swasta lebih fokus kepada Pembangunan Jaringan Tegangan Rendah dan Jaringan dalam rumah atau Building Wire. Hal ini dapat 
terlihat pada pembangunan Gedung-gedung bertingkat, Mall Perbelanjaan, Hotel dan Rumah Tinggal yang sangat memerlukan kabel Tegangan Rendah dan Building Wire. Sektor Swasta lebih dikenal dengan Sektor Pasaran Umum atau Sektor Retail. Pemilihan PT. Nusa Jayatama Mandiri sebagai bahan penelitian adalah karena perusahaan ini merupakan salah satu perusahaan pendukung pembangunan infrastruktur ketenagalistrikan, khususnya dalam pengadaan dan pemenuhan kabel sebagai produk material transmisi. Berdiri sejak 2010 dan berlokasi di Gedung Graha Pratama, lt. 20, Jl. MT. Haryono Kav. 15, Jakarta Selatan, perusahaan ini memfokuskan kepada bidang supplier produk kabel yang memiliki 197 karyawan. Kinerja perusahaan merupakan hal yang penting dalam meningkatkan persaingan. Setiap perusahaan dalam melaksanakan strategi untuk memenangkan persaingan harus mampu menggunakan sumber daya efektif dan efisien, sehingga visi dan misi perusahaan dapat tercapai. Hal ini merupakan tujuan dari perusahaan, yaitu bagaimana perusahaan dapat memperbaiki kinerja perusahaanya sehingga semua kebijakan yang tidak relevan dengan visi perusahaan akan dapat diperbaiki, sehingga semua pencapaian dimasa yang akan datang akan menjadi lebih baik. Persaingan bisnis yang semakin global dan makin intensif selayaknya memicu perusahaan untuk senantiasa berupaya merumuskan dan menyempurnakan strategi bisnisnya. Untuk mengetahui sejauh mana efektivitas penerapan strategi perusahaan harus mampu mengukur kinerja bisnisnya (Hardika dan Putra, 2018). Berikut merupakan data target output dan realisasi output perusahaan dalam 3 tahun terakhir.

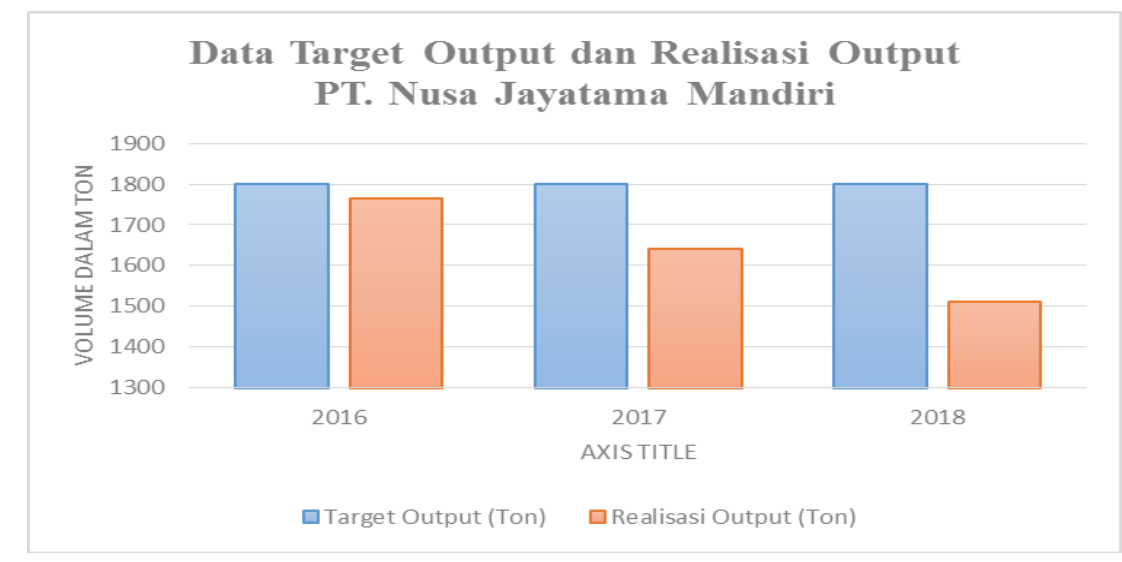

Sumber: Data perusahaan (2019)

Gambar 2. Data target output dan realisasi output perusahaan

Berdasarkan Gambar 2. realisasi output 2016 mengalami penurunan 255 ton yaitu tahun 2018 dari 1765 ton menjadi 1510 dan tidak mencapai target perusahaan sebesar 1800 ton. Hal ini membuat kinerja perusahaan menurun. Kinerja perusahaan merupakan hal penting dalam meningkatkan persaingan. Perusahaan harus melaksanakan strategi yang telah direncanakan untuk memenangkan persaingan, oleh karena itu harus mampu menggunakan sumber daya efektif dan efisien sehingga visi dan misi perusahaan dapat tercapai. (Hardika dan Putra, 2018). Penurunan output perusahaan disebabkan juga karena mutu produk yang belum optimal, ini ditunjukan dengan masih adanya beberapa komplain dari pembeli atau user. Belum adanya pola manajemen komunikasi internal yang baik juga menjadi penyebab lain. Hal ini terlihat dengan sibuknya pimpinan dengan kegiatan lain diluar kantor. Perusahaan juga hanya menggunakan standar produk SNI kabel yang dijadikan standar kerja untuk menghasilkan produk, tidak mempunyai standar mutu kerja lainnya. Dari sisi keunggulan produk, perusahaan hanya mengandalkan harga jual yang bersaing, tanpa 
memperhatikan hal lain yang juga dapat menjadi nilai tambah dari sisi pelayanan. (wawancara awal dengan karyawan perusahaan). Total quality management merupakan salah satu faktor yang mempengaruhi kinerja perusahaan. Menurut Heizer dan Render (2016) manajemen kualitas total (Total quality management) adalah manajemen dari keseluruhan organisasi sehingga unggul di segala aspek dari barang dan jasa yang penting bagi pelanggan. Manajemen kualitas total mengharuskan proses perbaikan yang tidak pernah berhenti yang mencakup orang, peralatan, pemasok, material, dan prosedur. Dasar falsafahnya aadalah setiap aspek sebuah operasional dapat diperbaiki. Tujuan akhir adalah kesempurnaan, yang tidak akan pernah dicapai, namun selalu dicari. Berikut merupakan pra kuisoner Total quality management.

Tabel 1. Pra Kuisioner Total Quality Management

\begin{tabular}{lccccc}
\hline Pernyataan & SS & S & N & TS & STS \\
\hline Saya mendapat pelatihan & 3 & 1 & 2 & 19 & 5 \\
\hline Saya berinovasi dalam bekerja & 2 & 4 & 1 & 5 & 18 \\
\hline Sum
\end{tabular}

Sumber: Hasil pra kuisioner 30 responden (2019)

Berdasarkan Tabel 1. mayoritas responden menjawab sebanyak 63\% karyawan tidak setuju mendapat pelatihan dan $60 \%$ responden menjawab sangat tidak setuju berinovasi dalam bekerja. Dapat disimpulkan bahwa karyawan kurang mendapat pelatihan dan kurang berinovasi dalam bekerja. Belum optimalnya penerapan Total quality management merupakan tantangan bagi perusahaan untuk dapat mempertahankan pangsa pasar dan memenangkan persaingan bisnis yang ketat (Hardika dan Putra, 2018). Selain Total quality management faktor selanjutnya yang mempengaruhi kinerja perusahaan adalah Quality management information. Menurut Widjaya dan Suryawan (2014) Quality management information adalah pengumpulan sistematis dan analisis data dalam siklus pemecahan masalah untuk mengidentifikasi masalah secara kritis, mencari penyebab masalah, dan menghasilkan solusi-solusi masalah. Quality management information merupakan hal yang penting dalam pengambilan keputusan, pengawasan kualitas, perencanaan kualitas, dan ukuran tersebut memberikan pengaruh langsung terhadap kualitas produk. Berikut merupakan hasil pra kuisioner Quality management information.

Tabel 2. Pra Kuisioner Quality management information

\begin{tabular}{lrrrrc}
\hline Pernyataan & SS & S & N & TS & STS \\
\hline Pimpinan selalu hadir setiap hari di perusahaan & 4 & 3 & 1 & 5 & 17 \\
\hline Saya dapat bekerja sama secara tim & 2 & 1 & 0 & 19 & 8 \\
\hline
\end{tabular}

Sumber: Hasil pra kuisioner 30 responden (2019)

Berdasarkan Tabel 2. dari 30 responden sebanyak 57\% sangat tidak setuju pimpinan selalu hadir setiap hari diperusahaan. Sebanyak $63 \%$ responden menjawab tidak setuju dapat bekerja secara tim. Dapat disimpulkan pimpinan tidak hadir setiap hari perusahaan dan karyawan tidak dapat bekerja sama secara tim. Implementasi yang efektif dari Quality management information akan meningkatkan kualitas produk dan memfasilitasi hubungan manajemen pemasok (Anh dan Matsui, 2011). Selain Total quality management dan Quality management information faktor yang mempengaruh kinerja perusahaan adalah keunggulan kompetitif. Menurut Porter (2008) dalam Asyhari, Pudjihastuti, Kurdaningsih (2018) keunggulan kompetitif adalah berkaitan dengan cara bagaimana perusahaan memilih dan melaksanakan strategi generik kedalam praktek. Keunggulan bersaing merupakan 
determinasi utama bagi kinerja perusahaan. Perusahaan memperoleh keuntungan dari penerapan strategi dan agar tidak tergerus oleh persaingan globalisasi maka perusahaan harus menciptakan keunggulan bersaing. Berikut merupakan pra kuisioner Keunggulan kompetitif.

\section{Tabel 3. Pra Kuisioner Keunggulan Kompetitif}

\begin{tabular}{llllll}
\hline Pernyataan & SS & S & N & TS & STS \\
\hline Persediaan kabel selalu tersedia dipasaran & 2 & 3 & 2 & 17 & 6 \\
\hline Harga kabel bersaing & 19 & 5 & 3 & 1 & 2 \\
\hline
\end{tabular}

Sumber: Hasil pra kuisioner 30 responden, (2019)

Berdasarkan Tabel 3. dari 30 responden sebanyak 56\% responden tidak setuju persediaan kabel dan 63\% setuju harga kabel bersaing. Dapat disiumpulkan persediaan kabel kurang tersedia di pasaran dan harga kabel bersaing dengan kompetitor. Perusahaan yang mampu menciptakan Keunggulan Kompetitif akan memiliki kekuatan untuk bersaing dengan perusahaan lain karena produknya tetap diminati oleh pelanggan (Asyhari, Pudjihastuti, Kurdaningsih, 2018). Berdasarkan uraian latar belakang diatas maka peneliti mengambil judul Analisa Pengaruh Total quality management, Quality management information dan Keunggulan kompetitif terhadap Kinerja perusahaan. 


\section{METODE}

Desain penelitian yang digunakan dalam penelitian ini yaitu menggunakan metode kuantitatif dengan rumusan masalah asosiatif. Menurut Saunders, Lewis, Thornhill (2016) penelitian kuantitatif umumnya dengan positivisme, terutama ketika digunakan dengan teknik pengumpulan data yang telah ditentukan dan sangat terstruktur. Metode penelitian kuantitatif dapat diartikan sebagai metode penelitian yang berlandaskan pada filsafat positivisme, digunakan untuk meneliti pada populasi atau sampel tertentu, pengumpulan data menggunakan instrumen penelitian, analisis data bersifat kuantitatif/statistik, dengan tujuan menguji hipotesis yang ditetapkan (Sugiyono, 2017). Rumusan masalah asosiatif adalah suatu rumusan masalah penelitian yang bersifat menanyakan hubungan antara dua variabel atau lebih. Time Horizon waktu yang digunakan dalam penelitian ini adalah cross sectional. Menurut Sekaran dan Bougie (2016) Cross sectional adalah sebuah penelitian dapat dilakukan dalam data mana yang dikumpulkan halnya sekali mungkin dalam periode beberapa hari atau minggu atau bulan untuk menjawab pertanyaan penelitian. Unit analisis dalam penelitian ini adalah individu yaitu karyawan perusahaan dengan menyebar kuisioner yang langsung dibagikan kepada karyawan.

Tabel 4. Desain Penelitian

\begin{tabular}{ccccc}
\hline $\begin{array}{c}\text { Tujuan } \\
\text { Penelitian }\end{array}$ & $\begin{array}{c}\text { Jenis } \\
\text { Penelitian }\end{array}$ & $\begin{array}{c}\text { Metode } \\
\text { Penelitian }\end{array}$ & Unit Analisis & Time Horizon \\
\hline T1 & Asosiatif & Kuantitatif & Individu (karyawan) & Cross-sectional \\
\hline T2 & Asosiatif & Kuantitatif & Individu (karyawan) & Cross-sectional \\
\hline T3 & Asosiatif & Kuantitatif & Individu (karyawan) & Cross-sectional \\
\hline T4 & Asosiatif & Kuantitatif & Individu (karyawan) & Cross-sectional \\
\hline
\end{tabular}

Sumber: diolah peneliti, (2020)

\section{Keterangan}

T1: Untuk mengetahui pengaruh Total quality management terhadap kinerja perusahaan.

T2: Untuk mengetahui pengaruh Quality management information terhadap kinerja perusahaan.

T3: Untuk mengetahui pengaruh keunggulan kompetitif terhadap kinerja.

T4: Untuk mengetahui pengaruh Total quality management, Quality management information dan keunggulan kompetitif berpengaruh secara bersama-sama terhadap Jenis Data

Kinerja perusahaan secara bersama-sama.

Menurut Saunders, Lewis, Thornhill (2016) penelitian kuantitatif umumnya dengan positivisme, terutama ketika digunakan dengan teknik pengumpulan data yang telah ditentukan dan sangat terstruktur. Metode penelitian kuantitatif dapat diartikan sebagai metode penelitian yang berlandaskan pada filsafat positivisme, digunakan untuk meneliti pada populasi atau sampel tertentu, pengumpulan data menggunakan instrumen penelitian, analisis data bersifat kuantitatif/statistik, dengan tujuan menguji hipotesis yang ditetapkan (Sugiyono, 2017).

\section{Sumber Data}

Menurut Sugiyono (2017) bila dilihat dari sumber datanya, maka pengumpulan data dapat menggunakan sumber primer, dan sumber sekunder. Sumber primer adalah sumber data yang langsung memberikan data kepada pengumpul data, dan sumber sekunder merupakan sumber 
yang tidak langsung memberikan data kepada pengumpul data, misalnya lewat orang lain atau lewat dokumen.

\section{Teknik Pengumpulan Data}

Menurut Sugiyono (2017) pengumpulan data berdasarkan tekniknya

1. Observasi

Observasi merupakan suatu proses yang komplek, suatu proses yang tersusun dari berbagai proses biologis dan psikologis. Dua diantaranya yang terpenting adalah prosesproses pengamatan dan ingatan.

2. Kuisioner

Kuisioner merupakan teknik pengumpulan data yang dilakuan dengan cara memberi seperangkat pertanyaan atau pernyataan tertulis kepada responden untuk dijawabnya. Kuisioner dapat berupa pertanyaan/pernyataan tertutup atau terbuka, dapat diberikan kepada responden secara langsung atau dikirim melalui pos atau internet. Pernyataan atau pertanyaan yang ada didalam kuisioner akan diukur dengan menggunakan skala Likert, dengan alternative jawaban $5=$ Sangat Setuju; $4=$ Setuju, $3=$ Netral, $2=$ Tidak Setuju dan 1 = Sangat Tidak Setuju. Menurut Sugiyono (2017) skala Likert digunakan untuk mengukur sikap, pendapat, dan persepsi seseorang atau sekelompok orang tentang fenomena sosial.

\section{Populasi}

Menurut Sugiyono (2017) populasi adalah wilayah generalisasi yang terdiri atas obyek/subyek yang mempunyai kualitas dan karakteristik tertentu yang ditetapkan oleh peneliti untuk dipelajari. Populasi dalam penelitian ini adalah kepada 197 Karyawan perusahaan.

\section{Sampel}

Menurut Sugiyono (2017) sampel adalah bagian dari jumlah dan karakterisitik yang dimiliki oleh populasi tersebut. Bila populasi besar, dan peneliti tidak mungkin mempelajari semua yang ada pada populasi, misalnya karena keterbatasan dana, tenaga dan waktu, maka peneliti dapat menggunakan sampel yang diambil dari populasi itu. Apa yang dipelajari dari sampel itu, kesimpulannya akan dapat diberlakukan untuk populasi. Untuk itu sampel yang diambil dari populasi harus betul-betul representatif (mewakili).

\section{Teknik Sampling}

Dalam penelitian ini menggunakan probability sampling. Menurut Sekaran dan Bougie (2016) probability sampling adalah desain sampling di mana unsur penduduk memiliki beberapa kesempatan yang diketahui atau probabilitas dipilih sebagai subyek sampel. Pengambilan sampel menggunakan simple random sampling. Menurut Sekaran dan Bougie (2016) simple random sampling adalah desain sampling probabilitas setiap elemen dalam populasi telah dikenal dan berkesempatan yang sama untuk dipilih sebagai subjek. Dalam penelitian ini yaitu karyawan tetap perusahaan dan untuk menentukan jumlah sampel peneliti menggunakan rumus Slovin sebagai berikut:

$S=\frac{N}{N \cdot d^{2}+1}$

Keterangan

$\mathrm{S}=$ Ukuran sampel

$\mathrm{N}=$ Ukuran populasi

$\mathrm{P}=$ Proporsi populasi umumnya 0,05

$\mathrm{Q}=1-\mathrm{p}$

$\mathrm{D}=$ Taraf signifikansi yang dikehendaki 
$\mathrm{S}=\frac{197}{197(0,05)^{2}+1}$

$\mathrm{S}=131,99=\mathbf{1 3 2}$ karyawan perusahaan .

\section{Skala Pengukuran}

Skala pengukuran yang dipakai dalam penelitian ini adalah Skala Ordinal. Skala Ordinal adalah skala yang didasarkan pada ranking, diurutkan dari jenjang yang lebih tinggi sampai jenjang terendah, atau sebaliknya. (Susanti, 2017).

\section{ANALISIS DAN PEMBAHASAN}

Dari hasil analisis data yang digunakan dengan metode regresi sederhana dan regresi berganda untuk mengetahui pengaruh Total Quality Management, Quality Management Information, dan Keunggulan kompetitif terhadap Kinerja perusahaan, maka dapat diperoleh hasil analisa penelitian dalam gambar di bawah ini:

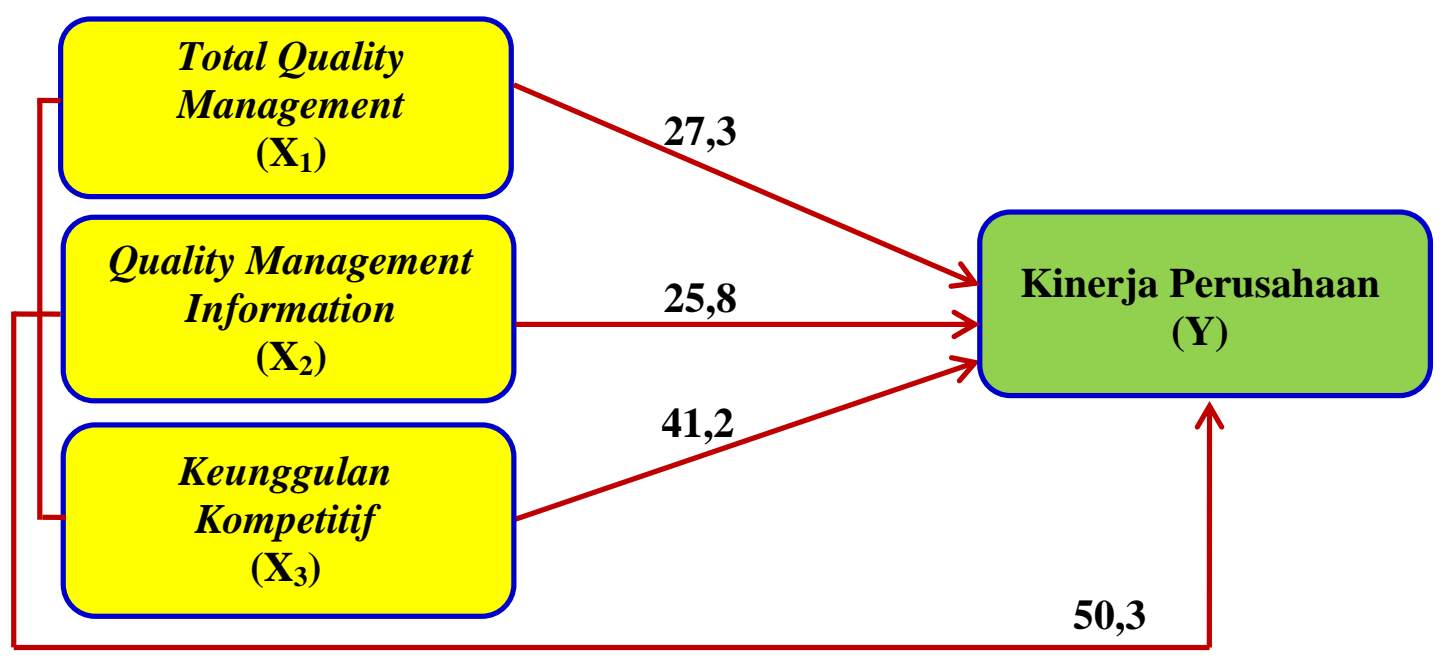

Gambar 3. Rerangka penelitian dari hasil penelitian

\section{Implikasi Hasil Penelitian}

Implikasi Teori

Tabel 3. Data perbandingan Jurnal dengan Penelitian Peneliti

\begin{tabular}{|c|c|c|}
\hline No & Hasil Penelitian Jurnal & Hasil Penelitian Peneliti \\
\hline 1 & $\begin{array}{c}\text { Total Quality Management terhadap } \\
\text { Kinerja Perusahaan = } \mathbf{0 , 3 9 6} \\
\text { (Suartina, Swara, Astiti, 2019) }\end{array}$ & $\begin{array}{c}\text { Total Quality Management } \\
\text { terhadap Kinerja Perusahaan = } \\
\mathbf{0 , 2 7 3}\end{array}$ \\
\hline 2 & $\begin{array}{l}\text { Quality Management Information } \\
\text { terhadap Kinerja Perusahaan = } \mathbf{0 , 5 2 4} \\
\text { (Widjaya dan Suryawan, 2014) }\end{array}$ & $\begin{array}{c}\text { Quality Management Information } \\
\text { terhadap Kinerja Perusahaan }= \\
\mathbf{0 , 2 5 8}\end{array}$ \\
\hline 3 & $\begin{array}{c}\text { Keunggulan Kompetitif terhadap } \\
\text { Kinerja Perusahaan = } \mathbf{0 , 3 9 9} \\
\text { (Munizu, 2013) }\end{array}$ & $\begin{array}{l}\text { Keunggulan Kompetitif terhadap } \\
\text { Kinerja Perusahaan }=\mathbf{0 , 4 1 2}\end{array}$ \\
\hline
\end{tabular}

Sumber: data diolah peneliti (2020)

Total Quality Management terhadap kinerja perusahaan pada Suartina, Swara, Astiti (2019) nilainya adalah 0,396, sedangkan Total Quality Management oleh peneliti 
nilainya adalah 0,273. Perbedaan ini disebabkan pada Suartina, Swara, Astiti (2019), produk yang diteliti adalah Busana Pria dan Wanita dari Industri Garmen, sedangkan pada penelitian peneliti, produk yang diteliti adalah Kabel Listrik yang mempunyai sifat dan karakteristik produk yang berbeda. Pada Busana maka Kualitas produk per satuan langsung dapat dirasakan oleh konsumen, begitu pula faktor kegagalan langsung berdampak, sedangkan pada Kabel Kualitas produk baru dapat dirasakan terlihat setelah digunakan dalam kurun waktu tertentu yang cukup lama, begitu pula faktor kegagalan sedikit yang terjadi masih tetap dapat digunakan dengan Batasan dan waktu tertentu. Itulah sebabnya Total Quality Management terhadap Kinerja perusahaan pada laporan Jurnal menjadi sangat penting dan mempunyai Nilai lebih besar dibandingkan dengan hasil penelitian Peneliti karena sifat dan karakteristik produk yang berbeda tersebut. Quality Management Information terhadap kinerja perusahaan pada Widjaya dan Suryawan (2014) nilainya adalah 0,524, sedangkan Quality Management Information pada penelitian peneliti nilainya adalah 0,258 . Nilai pada Jurnal lebih besar dari pada hasil peneliti, hal ini disebabkan oleh produk Dasi yang diteliti Jurnal mempunyai nilai mutu, seni dan desain yang sangatlah penting, sehingga kualitas komunikasi serta pengambilan keputusan antara pimpinan, manager dengan karyawan sangat penting, sehingga Quality Management Information mempunyai pengaruh yang sangat besar. Pada produk Kabel Listrik oleh Peneliti penerapan standar SNI lebih difokuskan, sehingga komunikasi manager lebih kepada pengawasan untuk memenuhi standar yang ada dan telah ditetapkan. Keunggulan kompetitif pada Munizu (2013) nilainya adalah 0,399, sedangkan pada peneliti nilainya 0,412 . Dalam hal ini karakteristik, sifat dan kondisi yang dihadapi oleh perusahaan pada penelitian Jurnal dan penelitian pada peneliti sangat berbeda. Perusahaan pada peneliti mempunyai nilai yang lebih besar pada Keunggulan Kompetitif dikarenakan produk Kabel Listrik sudah mempunyai standar produk SNI Kabel yang menjadi acuan, sehingga lebih mudah dalam mengejar Keunggulan Kompetitifnya, dibandingkan dengan produk olahan ikan pada penelitian di jurnal.

\section{Implikasi Aplikatif}

Berdasarkan hasil penelitian nilai Total Quality Management terhadap kinerja perusahaan mendapatkan nilai 0,273 , maka langkah yang perlu ditingkatkan oleh perusahaan adalah pelatihan terhadap karyawan secara berkesinambungan untuk memastikan kinerja perusahaan terus naik. Hasil penelitian Quality Management Information terhadap kinerja perusahaan mendapatkan nilai 0,258 maka hal yang akan dilakukan perusahaan adalah menjaga komunikasi dan pengertian yang baik terhadap karyawan untuk memastikan hasil dan kinerja Quality Management Informasinya lebih baik pada koridor yang tepat. Pada penelitian peneliti perihal Keunggulan Kompetitif terhadap Kinerja perusahaan mendapatkan hasil 0,412. Perusahaan akan tetap mencari poin-poin dan parameter tambahan lain yang dapat menjadi Keunggulan Kompetitif. 


\section{KESIMPULAN DAN SARAN}

Berdasarkan penyebaran kuisioner kepada karyawan perusahaan, dan dari rumusan masalah, tujuan, penelitian, dan hasil dari kerangka berpikir yang telah dibuat maka ditarik beberapa simpulan, sebagai berikut:

1. Total Quality Management memiliki nilai signifikansi sebesar 0,000 $<0,05$ maka Ho ditolak Ha diterima serta memiliki nilai standardized coefficients beta sebesar 0,273 yang artinya Total Quality Management berpengaruh positif dan signifikan terhadap Kinerja perusahaan.

2. Quality Managament Information memiliki nilai signifikasi sebesar 0,001 <0,05 maka Ho ditolak Ha diterima serta memiliki standardized coefficients beta sebesar 0,258 yang artinya Quality Management Information berpengaruh positif dan signifikan terhadap Kinerja perusahaan.

3. Keunggulan kompetitif memiliki nilai signifikansi sebesar $0,000<0,05$ maka Ho ditolak Ha diterima serta memiliki nilai standardized coefficients beta sebesar 0,412 yang artinya keunggulan kompetitif berpengaruh positif dan signifikan terhadap Kinerja perusahaan.

Total Quality Management, Quality Management Information, dan Keunggulan kompetitif memiliki pengaruh secara bersama sama sebesar 50,3\% terhadap Kinerja perusahaan. Hasil F tabel adalah 3,07. Nilai $\mathrm{F}$ hitung $>\mathrm{F}$ tabel $(45,259>3,07)$ maka Ho ditolak Ha diterima. Nilai signifikansi $0,000<0,05$ maka terdapat pengaruh yang signifkan. 


\section{DAFTAR PUSTAKA}

Alhudri, S \& Heriyanto, M. (2015). Pengaruh Penerapan Total Quality Management (TQM) Terhadap Kinerja Karyawan Pada PT. PLN (Persero) Ranting Bangkinang. Jurnal Online Mahasiswa Fakultas Ilmu Sosial dan Ilmu Politik 2(2). 1-14.

Anh, P. C., \& Matsui, Y. (2011). Relationship between quality management information and operational performance. Management Research Review 34(5), 519-540.

Asyhari, A., Pudjihastuti, S. H., \& Kurdaningsih, D. M. (2018). Peran mediasi keunggulan kompetitif pada faktor determinan kinerja bisnis UKM di sentra tenun batik di Jawa Tengah. Jurnal Siasat Bisnis, 22(2), 111-131.

Belay, A. M., Helo, P., Asyhari, A., Pudjihastuti, S. H., \& Kurdaningsih, D. M. (2018). Peran mediasi keunggulan kompetitif pada faktor determinan kinerja bisnis UKM di sentra tenun batik di Jawa Tengah. Jurnal Siasat Bisnis, 22(2), 111-131

Gani, I \& Amalia, S. (2018). Alat Analisis Data Aplikasi Statistik untuk Penelitian Bidang Ekonomi \& Sosial. Yogyakarta: Andi.

Goetsch, D. L., \& Davis, S. B. (2014). Quality Management for Organizational Excellence. Upper Saddle River: Pearson.

Hardika, A.L \& Putra, I.G.S. (2014). Pengaruh Strategi Keunggulan Bersaing dan Total Quality Management Terhadap Kinerja Perusahaan Dengan Karakteristik

Informasi Akuntansi Manajemen Sebagai Variabel Moderasi. Prosiding Forum Keuangan dan Bisnis V. 470-480

Hassan, M., Mukhtar, A., Qureshi, S. U., \& Sharif, S. (2012). Impact of TQM practices on firm's performance of Pakistan's manufacturing organizations.

International Journal of Academic Research in Business and Social Sciences, 2(10), 232-259

Heizer, J., \& Render, B. (2016). Operations Management. New Jersey: Pearson

Heryanto, I \& Triwibowo, T. (2018). Path Analysis Menggunakan SPSS dan Excel.. Bandung: Informatika.

Korankye, A. (2013). Total quality management (TQM): a source of competitive advantage. a comparative study of manufacturing and service firms in Ghana. International Journal of Asian Social Science, 3(6), 1293-1305.

Mintje, N. (2013). Pengaruh TQM, Sistem Penghargaan Dan Sistem Pengukuran Kinerja Terhadap Kinerja Manajerial Pada PT. Air Manado. Jurnal EMBA: Jurnal Riset Ekonomi, Manajemen, Bisnis dan Akuntansi, 1(3). 
Munizu, M. (2013). The Impact of total quality management practices towards competitive advantage and organizational performance: Case of fishery industry in South Sulawesi Province of Indonesia. Pakistan Journal of Commerce and Social Sciences (PJCSS), 7(1), 184-197.

Priyatno, D. (2018). SPSS Panduan Mudah Olah Data bagi Mahasiswa \& Umum. Yogyakarta: Andi.

Prayhoego, C \& Devie. (2013). Analisa Pengaruh Total Quality Management Terhadap Keunggulan Bersaing dan Kinerja Perusahaan. Business Accounting Review, 1(2), 236245.

Heryanto, I \& Triwibowo, T. (2018). Path Analysis Menggunakan SPSS dan Excel.. Bandung: Informatika.

Saundres, M, Lewis, P \& Tronhill H. (2016). Research Methods for Business Students seventh edition. Boston: Pearson.

Santoso, C. V. (2017). Analisis Fungsi Manajemen Operasional Pada PT. Puyuh Plastik. AGORA, 5(1).

Sekaran, U \& Bogie, R. (2016). Research Method for Business. West Sussex: Willey.

Suartina, I. W., Swara, N. N. A. A. V., \& Astiti, N. L. S. (2019). Pengaruh Total Quality Management (TQM) Terhadap Kinerja Perusahaan Melalui Perilaku

Produktif Karyawan Pada PT. Tommorrow's Aquaes Indonesia. Widya Manajemen, 1(2), 1-20.

Sugiyono. (2017). Metode Penelitian Kuantitatif, Kualitatif dan $R \& D$. Bandung: Alfabeta

Sutabri, T. (2012). Analisis Sistem Informasi. Yogyakarta: Andi.

Takala, J., \& Kasie, F. M. (2011). Effects of quality management practices and concurrent engineering in business performance. International Journal of Business and Management, 6(3), 45.

Talib, F., Rahman, Z., \& Qureshi, M. N. (2010). The relationship between total quality management and quality performance in the service industry: a theoretical model. International Journal of Business, Management and Social Sciences (IJBMSS), MultiCraft, 1(1), 113-128.

Widjaya, O. H., \& Suryawan, I. N. (2014). Pengaruh Total Quality Management dan

Quality Management Information Terhadap Kinerja Perusahaan. Media Bisnis 6 (2). 88-96. 